\title{
The European-Specific Mitochondrial Cluster J/T Could Confer an Increased Risk of Insulin-Resistance and Type 2 Diabetes: An Analysis of the m.4216T $>C$ and m.4917A > G Variants
}

\author{
D. Crispim', L. H. Canani², J. L. Gross², B. Tschiedel'2, K. E. P. Souto ${ }^{3}$ and I. Roisenberg',* \\ ${ }^{1}$ Departamento de Genética, Universidade Federal do Rio Grande do Sul, Porto Alegre, Rio Grande do Sul, Brazil \\ ${ }^{2}$ Divisão de Endocrinologia, Hospital de Clínicas de Porto Alegre, Universidade Federal do Rio Grande do Sul, Porto Alegre, \\ Rio Grande do Sul, Brazil \\ ${ }^{3}$ Serviço de Endocrinologia, Grupo Hospitalar Conceição, Porto Alegre, Rio Grande do Sul, Brazil
}

\begin{abstract}
Summary
The aims of this study were to investigate the contributions of the mitochondrial DNA m.4216T > C and m.4917A > G variants, and also of the European-specific mitochondrial cluster J/T, to the development of type 2 diabetes mellitus in Caucasian-Brazilian patients from Southern Brazil. We analyzed 347 type 2 diabetes patients and 350 control subjects. Variant frequencies in patients and control subjects were compared using $\chi^{2}$ tests or odds ratio. We also compared clinical and laboratory characteristics among patients with and without the variants. We found that the frequencies of the m.4216T $>\mathrm{C}$ and $\mathrm{m} .4917 \mathrm{~A}>\mathrm{G}$ variants are higher in diabetic patients than in control subjects. Moreover, haplogroups J (partially defined by the presence of the $\mathrm{m} .4216 \mathrm{~T}>\mathrm{C}$ variant only) and $\mathrm{T}$ (partially defined by the presence of both $\mathrm{m} .4216 \mathrm{~T}>\mathrm{C}$ and $\mathrm{m} .4917 \mathrm{~A}>\mathrm{G}$ variants) are more frequent in the type 2 diabetic group than in the control group. Patients belonging to the cluster $\mathrm{J} / \mathrm{T}$ are more insulin resistant than patients of other haplogroups. In conclusion, our results indicate the association of the cluster $\mathrm{J} / \mathrm{T}$ (as suggested by analyses of the $\mathrm{m} .4216 \mathrm{~T}>\mathrm{C}$ and $\mathrm{m} .4917 \mathrm{~A}>\mathrm{G}$ variants) with insulin resistance and type 2 diabetes.
\end{abstract}

\section{Introduction}

Type 2 diabetes mellitus (DM) seems to be maternally transmitted in some families and a mitochondrial origin has been postulated (Alcolado \& Alcolado, 1991; Thomas et al. 1994). Since mitochondrial oxidative phosphorylation (OXPHOS) plays an important role in glucose-stimulated insulin secretion in beta cells, defects in mitochondrial genes are plausible causative agents for DM (Kadowaki et al. 1994). An A to G substitution at position 3243 of the mitochondrial tRNA ${ }^{\text {Leu(UUR) }}$ gene

\footnotetext{
* Corresponding author: Israel Roisenberg, Departamento de Genética, Instituto de Biociências, Universidade Federal do Rio Grande do Sul, Caixa Postal 15053, Porto Alegre, RS, Brazil, 91501-970. Tel: + 5551 3316-6716; Fax: + 5551 3316-7311. E-mail: israberg@ufrgs.br
}

is the most commonly reported defect associated with DM. This variant was first described as being associated with the encephalomyopathy, lactic acidosis, and stroke-like episodes (MELAS) syndrome (Goto et al. 1990), and was more recently recognized as a cause of the maternally inherited DM and deafness (MIDD) syndrome (Reardon et al. 1992; van den Ouweland et al. 1992). Nevertheless, the m.3243A > G variant has been reported in only $1-2 \%$ of patients with type $2 \mathrm{DM}$ (Gerbitz et al. 1995).

Recently, a number of other mitochondrial variants have been reported in some families presenting maternal transmission of type 2 DM (Alcolado et al. 2002). However, an important question is the prevalence of these variants amongst patients with type $2 \mathrm{DM}$. Taking this into consideration, Perucca-Lostanlen et al. (2000) reported that in a group of French patients with features

(C) 2006 University College London No claim to original US government works 
of MIDD $66.0 \%$ had a $\mathrm{T}$ to $\mathrm{C}$ substitution at position 4216 of the NADH-dehydrogenase (ND) subunit 1 gene (m.4216T > C variant), and 55.0\% had an A to G substitution at position 4917 of the ND subunit 2 gene (m.4917A > G variant). However the authors found these variants in similar frequencies in both the type 2 diabetic group $(8.3 \%$ for the m.4216T $>\mathrm{C}$ variant and $4.2 \%$ for the m.4917A $>\mathrm{G}$ variant) and the control group $(12.3 \%$ for the $\mathrm{m} .4216 \mathrm{~T}>\mathrm{C}$ variant and $9.2 \%$ for the m.4917A $>\mathrm{G}$ variant). Both $\mathrm{m} .4216 \mathrm{~T}>\mathrm{C}$ and m.4917A > G variants cause an amino acid change in the MT-ND1 (Tyr/His) and MT-ND2 (Asp/Asn) gene products, respectively, and are homoplasmic. Nonetheless, these variants have not been investigated in other diabetic populations, but have been described as secondary mutations involved in the pathogenesis of Leber's hereditary optic neuropathy (LHON) (Carelli et al. 2003), and as neutral polymorphisms in linkage with a common European-specific mitochondrial cluster (haplogroups J and T) (Herrnstadt et al. 2002). Following on from these studies, we decided to investigate the contributions of the $\mathrm{m} .4216 \mathrm{~T}>\mathrm{C}$ and $\mathrm{m} .4917 \mathrm{~A}>\mathrm{G}$ variants, and of the haplogroups $\mathrm{J}$ and $\mathrm{T}$, to the development of type $2 \mathrm{DM}$ in Caucasian-Brazilian patients from Southern Brazil.

\section{Materials and Methods}

\section{Subjects}

This case-control study was carried out with 347 unrelated Caucasian-Brazilian type 2 diabetic patients who are participating in a multicentre study in the Brazilian State of Rio Grande do Sul. Type 2 DM was diagnosed according the criterion of The Expert Committee on the Diagnosis and Classification of Diabetes Mellitus (1997). The non-diabetic control group was composed of 350 Caucasian-Brazilian subjects with normal fasting plasma glucose, without any known chronic diseases, and collected from the same hospitals as the patients. Ethnic definition was based on self report. Subjects with uncertain ethnic definition were excluded from the study. In summary, the studied subjects descend from European populations, especially from Portugal, Spain, Italy, and Germany. Written informed consent was obtained from all subjects and the study was approved by the Hospitals' Ethical Committees.
All patients underwent a standardized clinical and laboratory evaluation. Sitting blood pressure (BP) was measured twice after a 5-min rest using a mercury sphygmomanometer. The mean value of two measurements was used to calculate systolic and diastolic BP. Hypertension was defined as BP levels $\geq 140 / 90 \mathrm{mmHg}$ or the use of antihypertensive drugs. Weight and height were used to calculate body mass index $\left(\mathrm{kg} / \mathrm{m}^{2}\right)$. Diabetic retinopathy was assessed by ophthalmoscopic examination and classified as absent, nonproliferative, or proliferative. Renal status was based on the albumin excretion rate (AER) in at least two out of three consecutive 24-h timed collections. Patients were classified as normo- $($ AER $<20 \mu \mathrm{g} / \mathrm{min}$ ), micro- (AER 20$199 \mu \mathrm{g} / \mathrm{min}$ ), or macroalbuminurics (AER > $200 \mu \mathrm{g} / \mathrm{min}$ ). The diagnosis of distal sensory neuropathy was based on abnormal results of Achilles tendon reflexes and vibration or sensory perception. Insulin resistance was estimated according to homeostasis model assessment (HOMA): fasting serum insulin $(\mathrm{pmol} / \mathrm{l}) \times$ fasting plasma glucose $(\mathrm{mmol} / \mathrm{l}) / 22.5$, in a subgroup of 120 patients not having insulin therapy and with serum creatinine $<132 \mu \mathrm{mol} / 1$.

\section{Laboratory Methods}

Blood glucose was determined using the glucose oxidase method; serum creatinine by the Jaffé reaction; glycated haemoglobin (HbA1c) by ion-exchange HPLC (Merck-Hitachi L-9100 GhB Analyser, reference range: 4.7-6.0\%); total plasma cholesterol and triglycerides by enzymatic methods; urinary albumin concentration by immunoturbidimetry (Sera-Pak immuno microalbuminuria, Bayer, Tarrytown, NY); C-peptide levels by radioimmunoassay (Diagnostic System Laboratories Incorporation, Webster, USA); and serum insulin by electrochemiluminescence (Elecsys R Systems/2010 ROCHE, sensitivity $0.2 \mathrm{uUI} / \mathrm{mL}$, mean intra- and interassay CV: 2.0 and 5.96\%, reference range 2.6$24.9 \mathrm{uUI} / \mathrm{mL})$.

\section{Genotyping}

DNA was extracted from peripheral blood samples, and the presence of the m.4216T > C and m.4917A > $\mathrm{G}$ variants determined by PCR-restriction fragment 
length polymorphism analysis and polyacrylamide gel electrophoresis. To detect the m.4216T $>\mathrm{C}$ variant, we subjected DNA samples to PCR with the forward primer 5'ACTCACCCTAGCATTACTTATATCEA $3^{\prime}$ (np4191-4215) and reverse primer 5'ATTTAGCTGACCTTACTTTACGATG3' (np4384-4418). The underlined position in the first primer represents a modification from the wild-type sequence to create an NdeI restriction site in this sequence: the 228bp PCRfragment of the wild-type allele can then be cleaved into two fragments of $203 \mathrm{bp}$ and $25 \mathrm{bp}$. For the screening the m.4917A > G variant we used the forward primer $5^{\prime}$ TACCAAATCTCTCCCTCACTㅡㅡ $3^{\prime}$ (np4896-4916) and the reverse primer 5'ATGGTTATGTTAGGGTTGTACG3' (np5053-5074). The underlined nucleotide creates a TaqI restriction site in the m.4917A > G mutant sequence: the 179bp PCRfragment can then be cleaved into two fragments of 157bp and 22bp. All experiments involving enzymatic digestion were carried out with positive control samples, whose genotypes were known following automated sequencing of the PCR fragment. In addition, we also sequenced a selection of subjects without the two variants $(n=20)$ to ensure they were not false-negatives. Duplicate samples were assessed for every subject in different gel loadings. In rare cases of ambiguous readins, sequencing of the PCR product was conducted in a MegaBace 1000 (GE HealthCare) system.

The m.4216T > C variant is reported to be one of the defining polymorphisms for the mtDNA cluster $\mathrm{J} / \mathrm{T}$ (Finnila et al. 2001; Herrnstadt et al. 2002). It can occur in association with the m.4917A > G variant (in part defining the haplogroup $\mathrm{T}$ ) or in association with the m.13708G > A variant in the ND subunit 5 gene (in part defining the haplogroup J). However, a few subjects with other haplogroups can also present these variants (Herrnstadt et al. 2002). Thus, in order to confirm the haplogroups of the subjects carrying the $\mathrm{m} .4216 \mathrm{~T}>\mathrm{C}$ and m.4917A $>$ G variants, we screened additional J/T specific polymorphisms as previously described (AlvesSilva et al. 2000).

For this study we excluded patients carrying the MIDD associated m.3243A > G variant. This was to ensure that the effects caused by this variant would not be a confounding factor for our conclusions. The method used for the screening of the m.3243A > G variant was as described by Katagiri et al. (1994).

\section{Statistical Methods}

Data are presented as means $\pm \mathrm{SD}$ or $\%(\mathrm{n})$. Variant frequencies in patients and control subjects were compared using the $\chi^{2}$ test, likelihood ratio test, Fisher's exact test or odds ratio (OR). ANOVA or $\chi^{2}$ tests were used to compare the clinical and laboratory characteristics among three groups of diabetic patients: 1. patients without the $\mathrm{m} .4216 \mathrm{~T}>\mathrm{C}$ and $\mathrm{m} .4917 \mathrm{~A}>\mathrm{G}$ variants; 2. patients with the $\mathrm{m} .4216 \mathrm{~T}>\mathrm{C}$ variant only (hap$\log$ roup J); and 3. patients with both the m.4216T > $\mathrm{C}$ and $\mathrm{m} .4917 \mathrm{~A}>\mathrm{G}$ variants (haplogroup T). When a difference among the groups was detected, pairwise comparisons or analyses of the normalized residuals were carried out, as appropriate. Multiple logistic regression analyses were performed to evaluate the association of different variables with the haplogroups $\mathrm{J}$ or $\mathrm{T}$, as well as to control for possible confounding factors, whenever a statistically significant association was found in the univariate analyses. Separate analyses looked for the presence of haplogroup J and haplogroup T. Variables with a skewed distribution were logarithmically transformed before analyses and are presented as medians (range). All analyses were performed using the SPSS version 10.0 program, and a two-tailed probability value of $\mathrm{P}<0.05$ was considered significant.

\section{Results}

\section{Frequencies of the m.4216 $\mathrm{T}>\mathrm{C}$ and m.4917A $>$ G Variants and of the Haplogroups $J$ and $T$ amongst Type 2 Diabetic Patients and Control Subjects}

The frequencies of the m.4216T $>\mathrm{C}$ and $\mathrm{m} .4917 \mathrm{~A}>$ $\mathrm{G}$ variants and of the cluster $\mathrm{J} / \mathrm{T}$ are shown in Table 1. In the present study we observed that the frequencies of the m.4216T > C and m.4917A > G variants are higher in the diabetic patients than in the control subjects. Consequently, both haplogroups $\mathrm{J}$ and $\mathrm{T}$ are more frequent in the type 2 diabetic group as compared to the control group. 
Table 1 Frequencies of the m.4216T > C and m.4917A > G variants and of haplogroups $\mathrm{J}$ and $\mathrm{T}$ in type 2 diabetic patients and in control subjects

\begin{tabular}{|c|c|c|c|}
\hline & $\begin{array}{l}\text { Diabetic patients } \\
(\mathrm{n}=347)\end{array}$ & $\begin{array}{l}\text { Control subjects } \\
(\mathrm{n}=350)\end{array}$ & $\begin{array}{l}\text { OR }(95 \% \mathrm{CI}) \\
\mathrm{P}^{\mathrm{a}}\end{array}$ \\
\hline \multicolumn{4}{|l|}{$\mathrm{m} .4216 \mathrm{~T}>\mathrm{C}$ variant } \\
\hline + (allele C) & $18.2(63)$ & $8.3(29)$ & $2.5(1.5-3.9)$ \\
\hline$-($ allele T) & $81.8(284)$ & $91.7(321)$ & $<0.001$ \\
\hline \multicolumn{4}{|l|}{ m.4917A > G variant } \\
\hline + (allele G) & $10.6(37)$ & $4.6(16)$ & $2.5(1.4-4.6)$ \\
\hline - (allele A) & $89.4(310)$ & $95.4(334)$ & 0.004 \\
\hline \multicolumn{4}{|l|}{ Haplogroup J } \\
\hline$+(4216 \mathrm{C})$ & $8.4(29)$ & $2.9(10)$ & $3.1(1.5-6.5)$ \\
\hline$-(4216 \mathrm{~T})$ & $91.6(318)$ & $97.1(340)$ & 0.003 \\
\hline \multicolumn{4}{|l|}{ Haplogroup $\mathrm{T}^{\mathrm{c}}$} \\
\hline$+(4216 \mathrm{C} / 4917 \mathrm{G})$ & $9.8(34)$ & $4.6(16)$ & $2.3(1.2-4.2)$ \\
\hline$-(4216 \mathrm{~T} / 4917 \mathrm{~A})$ & $90.2(312)$ & $95.4(334)$ & 0.012 \\
\hline
\end{tabular}

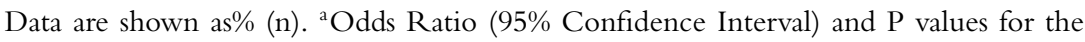
comparisons of frequencies between patients and controls. ${ }^{\mathrm{b}}$ Haplogroup $\mathrm{J}=$ presence of the $\mathrm{m} .4216 \mathrm{~T}>\mathrm{C}$ variant only; ${ }^{\mathrm{C}}$ Haplogroup $\mathrm{T}=$ presence of both $\mathrm{m} .4216 \mathrm{~T}>\mathrm{C}$ and m.4917A > G variants. Three patients had only the m.4917A > G variant, thus they do not belong to haplogroup T. Three control subjects with the m.4216T $>\mathrm{C}$ variant had other haplogroups rather than J.
We screened additional polymorphisms associated with the haplogroups $\mathrm{J}$ and $\mathrm{T}$, to make sure that the subjects carrying the $\mathrm{m} .4216 \mathrm{~T}>\mathrm{C}$ and $\mathrm{m} .4917 \mathrm{~A}>\mathrm{G}$ variants really had one of these two haplogroups. Three patients presented the m.4917A > G variant only; thus they do not belong to the haplogroup T. In addition, we found three control subjects that, despite having the m.4216G > C variant, do not belong to haplogroup J. These six subjects were excluded from the analyses of frequencies of haplogroups $\mathrm{J}$ and $\mathrm{T}$.

\section{Influence of the m.4216T $>C$ and m.4917A $>\mathrm{G}$ Variants and Haplogroups $\mathrm{J}$ and $\mathrm{T}$ on the Clinical and Laboratory Characteristics of Type 2 DM}

The clinical and laboratory characteristics of type 2 DM were compared among three groups of patients (Table 2): 1. patients without the $\mathrm{m} .4216 \mathrm{~T}>\mathrm{C}$ and m.4917A $>$ G variants; 2. patients with only the $\mathrm{m} .4216 \mathrm{~T}>\mathrm{C}$ variant (haplogroup J); and 3. patients with both variants (haplogroup $\mathrm{T}$ ). Three patients carrying only the m.4917A > G variant were excluded from the analyses. Our results indicate that patients of the cluster J/T present higher HOMA-insulin resistance values when compared to patients without the $\mathrm{m} .4216 \mathrm{~T}$ $>\mathrm{C}$ and $\mathrm{m} .4917 \mathrm{~A}>\mathrm{G}$ variants $(\mathrm{p}=0.001)$. Apart from this, patients of the cluster $\mathrm{J} / \mathrm{T}$ more frequently have a clear maternal history of type 2 DM than patients with other haplogroups $(\mathrm{p}=0.001)$.

When multiple logistic regression analyses were performed using age at patient's examination, gender, BMI and HOMA-insulin resistance as independent risk factors, and the presence of the haplogroup $\mathrm{J}$ or of the haplogroup $\mathrm{T}$ as the dependent variable, we observed that HOMA-insulin resistance remained significantly associated with haplogroups $\mathrm{J}$ and $\mathrm{T}$, independent of the presence of the other variables used in the logistic regressions (Table 3).

\section{Discussion}

Our study indicates that the m.4216T $>\mathrm{C}$ and m.4917A > G variants, and consequently the cluster $\mathrm{J} / \mathrm{T}$, are possibly associated with type $2 \mathrm{DM}$ and HOMA-insulin resistance in Caucasian-Brazilian patients. The first concern regarding this finding is whether our results could be misleading due to undetected population stratification in our samples. However, we find this possibility unlikely: only Caucasian-Brazilian subjects were studied, and both type 2 diabetic patients and control subjects were recruited from the same hospitals. Thus, despite some degree of genetic admixture in the self-declared 


\section{Crispim et al.}

Table 2 Clinical and laboratory characteristics of type 2 diabetic patients subdivided according to the presence of the $\mathrm{m} .4216 \mathrm{~T}>\mathrm{C}$ and $\mathrm{m} .4917 \mathrm{~A}>\mathrm{G}$ variants

\begin{tabular}{|c|c|c|c|c|}
\hline Characteristics & $\begin{array}{l}\text { Patients without } \\
\text { the } \mathrm{m} \cdot 4216 \mathrm{~T}>\mathrm{C} \text { and } \\
\text { and } \mathrm{m} \cdot 4917 \mathrm{~A}>\mathrm{G} \text { variants }\end{array}$ & $\begin{array}{l}\text { Patients with only } \\
\text { the } \mathrm{m} .4216 \mathrm{~T}>\mathrm{C} \\
\text { variant (haplogroup J) }\end{array}$ & $\begin{array}{l}\text { Patients with both the } \\
\mathrm{m} .4216 \mathrm{~T}>\mathrm{C} \text { and } \mathrm{m} .4917 \mathrm{~A}>\mathrm{G} \\
\text { variants (haplogroup } \mathrm{T} \text { ) }\end{array}$ & $\mathrm{P}^{\mathrm{a}}$ \\
\hline $\mathrm{N}$ & 284 & 29 & 34 & - \\
\hline Sex (\% male) & 39.3 & 33.3 & 35.3 & 0.991 \\
\hline Age (years) & $57.8 \pm 11.2$ & $55.7 \pm 11.6$ & $59.4 \pm 11.4$ & 0.358 \\
\hline Age at diagnosis (years) & $46.1 \pm 12.2$ & $47.1 \pm 10.1$ & $45.6 \pm 12.5$ & 0.652 \\
\hline Body mass index $\left(\mathrm{kg} / \mathrm{m}^{2}\right)$ & $28.9 \pm 5.5$ & $28.6 \pm 5.6$ & $28.6 \pm 4.4$ & 0.994 \\
\hline HbA1c $(\%)$ & $7.0 \pm 1.9$ & $7.8 \pm 2.2$ & $7.0 \pm 1.8$ & 0.476 \\
\hline Blood glucose (mmol/l) & $9.8 \pm 4.0$ & $8.5 \pm 3.6$ & $10.1 \pm 3.4$ & 0.624 \\
\hline Total cholesterol (mmol/l) & $5.6 \pm 1.3$ & $5.9 \pm 1.3$ & $5.4 \pm 1.3$ & 0.410 \\
\hline Triglycerides (mmol/l) & $1.6(0.3-16.6)$ & $1.8(0.5-5.0)$ & $1.9(0.7-4.6)$ & 0.506 \\
\hline Serum creatinine $(\mu \mathrm{mol} / \mathrm{l})$ & $81.3(35.3-733.7)$ & $87.5(44.2-636.5)$ & $96.4(53.0-636.5)$ & 0.202 \\
\hline Hypertension (\%) & 61.2 & 60.0 & 67.6 & 0.723 \\
\hline C-peptide (nmol/l) & $1.0 \pm 0.6$ & $1.2 \pm 0.5$ & $1.0 \pm 0.7$ & 0.315 \\
\hline Retinopathy (\%) & 43.1 & 46.1 & 48.3 & 0.891 \\
\hline Nephropathy (\%) & 37.0 & 34.0 & 44.8 & 0.676 \\
\hline Distal sensory neuropathy (\%) & 41.0 & 50.0 & 50.1 & 0.801 \\
\hline HOMA-insulin resistance $e^{b, c}$ & $4.9(0.3-75.2)^{\mathrm{A}}$ & $9.8(4.1-144.1)^{\mathrm{B}}$ & $12.4(0.3-87.3)^{\mathrm{B}}$ & 0.016 \\
\hline Insulin treatment $(\%)$ & 37.3 & 43.8 & 51.7 & 0.176 \\
\hline Clear maternal history $(\%)^{c, d}$ & $31.5^{\mathrm{A}}$ & $55.7^{\mathrm{B}}$ & $63.5^{\mathrm{B}}$ & 0.001 \\
\hline
\end{tabular}

Data are shown as means $\pm \mathrm{SD}, \%$ or median (range). ${ }^{\text {a }}$ for comparisons among the three groups. ${ }^{\mathrm{b}} \mathrm{HOMA}$ (homeostasis model assessment)-insulin resistance was measured only in a subgroup of 120 patients not having insulin treatment. ${ }^{\mathrm{C}}$ Statistically significant differences in means or $\%$ are indicated by different capital letters. Means and $\%$ which did not differ significantly at $\alpha<0.05$ are indicated by the same capital letter. ${ }^{\mathrm{d}}$ Clear maternal history is the presence of maternal type $2 \mathrm{DM}$ in three consecutive generations or through two consecutive generations with at least three affected individuals.

\begin{tabular}{|c|c|c|}
\hline Variable & $\begin{array}{l}\text { Patients with only } \\
\text { m.4216T > C variant } \\
\text { (haplogroup J) }\end{array}$ & $\begin{array}{l}\text { Patients with both } \\
\mathrm{m} .4216 \mathrm{~T}>\mathrm{C} \text { and } \mathrm{m} .4917 \mathrm{~A}>\mathrm{G} \\
\text { variants (haplogroup } \mathrm{T} \text { ) }\end{array}$ \\
\hline $\begin{array}{l}\text { Age at patient's } \\
\text { examination }\end{array}$ & $0.95(0.87-1.04) ; \mathrm{P}=0.267$ & $0.93(0.81-1.05) ; \mathrm{P}=0.252$ \\
\hline Gender & $4.23(0.67-26.37) ; \mathrm{P}=0.123$ & $1.04(0.358-3.39) ; \mathrm{P}=0.938$ \\
\hline $\begin{array}{l}\text { Body mass } \\
\text { index }\end{array}$ & $1.07(0.86-1.31) ; \mathrm{P}=0.528$ & $0.96(0.79-1.2) ; \mathrm{P}=0.709$ \\
\hline $\begin{array}{l}\text { HOMA-insulin } \\
\text { resistance }\end{array}$ & $5.20(1.34-19.17) ; \mathrm{P}=0.035$ & $7.45(1.30-22.71) ; \mathrm{P}=0.024$ \\
\hline
\end{tabular}

Table 3 Odds ratio adjusted by logistic regression for association with the haplogroup $\mathrm{J}$ or haplogroup $\mathrm{T}$ in type 2 diabetic patients

Results are presented as odds ratio (95\% Confidence Interval); P value.

Caucasian-Brazilian population being known (AlvesSilva et al. 2000), it is hard to imagine that both groups could have different admixture levels. Additionally, an independent study carried out in the same patient and control groups (Carlessi et al. 2004) did not find statistically significant differences between these groups for a nuclear polymorphism (UCP2, uncoupling protein-2 gene, exon 8 insertion/deletion) for which Caucasian-Brazilians and African-Brazilians have significantly different frequencies (Daisy Crispim, unpublished results), similar to results observed in other populations (Yanovski et al. 2000).

Our findings on the frequencies of the $\mathrm{m} .4216 \mathrm{~T}>$ $\mathrm{C}$ and $\mathrm{m} .4917 \mathrm{~A}>\mathrm{G}$ variants conflict with the report of Perucca-Lostanlen et al. (2000) in a French type 2 diabetic population. These authors found the m.4216T $>\mathrm{C}$ variant in $8.3 \%$ of the type 2 diabetic group and in $12.3 \%$ of the control group. They also reported that the 
$\mathrm{m} .4917 \mathrm{~A}>\mathrm{G}$ variant was present in $4.2 \%$ of the type 2 diabetic group and in $9.2 \%$ of the control group. One of the factors that could account for the discrepancies between our results and the findings of Perucca-Lostanlen et al. (2000) is the small number of patients analyzed in the latter study (24 type 2 diabetic patients and 65 control subjects). Alternatively, differences in genetics as well as environmental backgrounds between the Brazilian and French populations could be a reason why the $\mathrm{m} .4216 \mathrm{~T}>\mathrm{C}$ and $\mathrm{m} .4917 \mathrm{~A}>\mathrm{G}$ variants were only found to be associated with type 2 DM in the Brazilian population.

Unlike many pathogenic mutations the m.4216T > C and m.4917A > G variants are homoplasmic, which is generally considered to reflect a neutral variation. In fact, some studies have suggested that these variants are possibly neutral polymorphisms associated with the European specific cluster $\mathrm{J} / \mathrm{T}$ (Finnila et al. 2001; Herrnstadt et al. 2002). However, these variants have also been reported as associated with LHON (Carelli et al. 2003), Parkinson's disease (Ross et al. 2003), the diabetes insipidus, diabetes mellitus, optic atrophy and deafness (DIDMOAD) syndrome (Hofmann et al. 1997) and multiple sclerosis (Kalman et al. 1995). In the pathogenesis of LHON, they are thought to exacerbate the effects of the primary LHON mutations, but are not sufficient by themselves to cause visual loss, since they can be found both in LHON pedigrees (with primary mutations) and in healthy subjects mostly belonging to the cluster J/T (Torroni et al. 1997; Brown et al. 2002). For example, $70.0 \%$ of the European patients carrying the primary $\mathrm{T}$ to $\mathrm{C}$ LHON mutation at np14484 belong to haplogroup J, while about $10.0 \%$ of healthy subjects belong to this haplogroup (Brown et al. 1997).

There are scarce and controversial functional studies of the m.4216T > C and m.4917A > G variants. Vergani et al. (1995), evaluating the mitochondrial respiratory function in cybrid cells of patients with primary LHON mutations, reported that in a specific mtDNA background (haplogroup J) the secondary m.4216T > C variant may act synergistically, increasing the severity of a defect in OXPHOS. In opposition, Lodi et al. (2000) found that the m.4216T > C variant did not further impair brain and skeletal muscle OXPHOS in subjects with the primary G to A LHON mutation at $\mathrm{np} 11778$, as assessed by phosphorus magnetic reso- nance spectroscopy. Moreover, mitochondrial activity in platelets from healthy subjects with haplogroups $\mathrm{J}$ or $\mathrm{T}$ did not differ from that found in subjects without these haplogroups (Carelli et al. 1999). Additional studies are needed to clarify the functional role of the $\mathrm{m} .4216 \mathrm{~T}$ $>\mathrm{C}$ and m.4917A > G variants, and also to investigate their interaction with nuclear and environmental factors.

We observed that patients of the cluster $\mathrm{J} / \mathrm{T}$ present a more severe HOMA-insulin resistance as compared to patients not belonging to this cluster. Is there any biological plausibility for the association of cluster $\mathrm{J} / \mathrm{T}$ with insulin resistance? Recent studies have shown that ATP availability in muscle has an important role in insulin sensibility (Lee, 2001; Kelley et al. 2002; Petersen et al. 2003, 2004). Petersen et al. (2004) demonstrated that insulin resistance in the young offspring of type 2 diabetic patients is due to a dysregulation in intramyocellular fatty acid metabolism, which may be caused by an inherited defect in OXPHOS. Even the common m.16189T > $\mathrm{C}$ variant in the mitochondrial D-loop has been reported as being possibly associated with insulin resistance (Poulton et al. 1998). Considering these studies it is conceivable that defects in the mitochondrial energy machinery could be associated with insulin resistance due to a variation in ATP concentration in muscle, possibly caused by the m.4216T > C and m.4917A > G variants. However, as implied by their occurrence in control subjects, these variants are not sufficient by themselves to cause noticeable insulin resistance and type 2 DM. Thus additional mtDNA and nuclear variants, as well as environmental risk factors, might be involved. We cannot exclude the possibility that these variants could be neutral polymorphisms within the cluster $\mathrm{J} / \mathrm{T}$ and are only segregating with truly pathogenic mutations.

In conclusion, our results indicate an association of the cluster $\mathrm{J} / \mathrm{T}$ (as suggested by analyses of the $\mathrm{m} .4216 \mathrm{~T}>$ $\mathrm{C}$ and $\mathrm{m} .4917 \mathrm{~A}>\mathrm{G}$ variants) with insulin resistance and type 2 DM in Southern Brazil. However, since the m.4216T > C and m.4917A > G variants probably have only a subtle effect on mitochondrial function, they might be associated with other genetic or environmental factors in the onset of insulin resistance and type 2 DM. Further studies are required to confirm the biochemical effects of these variants in mitochondrial function and their role in the pathogenesis of the type 2 DM.

Annals of Human Genetics (2006) 70,488-495 
The authors would like to acknowledge Dr. Mara Helena Hutz (UFR GS, RS, Brazil) for kindly supplying the control group; Dr. Sandro Bonatto (PUCRS, RS, Brazil) for supplying the primers for the confirmation of haplogroups J and T; and Msc. Nelson J.R. Fagundes for critical comments on this manuscript. This research was supported by grants from Conselho Nacional de Desenvolvimento Científico e Tecnológico; Programa de Apoio a Núcleos de Excelência; and Financiadora de Estudos e Projetos.

\section{References}

Alcolado, J. C. \& Alcolado, R. (1991) Importance of maternal history of non-insulin-dependent diabetic patients. BMJ 302, 1178-1180.

Alcolado, J. C., Laji, K. \& Gill-Randall, R. (2002) Maternal transmission of diabetes. Diabet Med 19, 89-98.

Alves-Silva, J., Santos, M. S., Guimarães, P. E. M., Ferreira, A. C. S., Bandelt, H. J., Pena, S. D. J. \& Prado, V. F. (2000) The ancestry of Brazilian mtDNA lineages. Am J Hum Genet 67, 444-461.

Brown, M. D., Sun, F. \& Wallace, D. C. (1997) Clustering of Caucasian Leber hereditary optic neuropathy patients containing the 11778 or 1484 mutations on an mtDNA lineage. Am J Hum Genet 60, 381-387.

Brown, M. D., Starikovskaya, E., Derbeneva, O., Hosseini, S., Allen, J. C., Mikhailovskaya, I. E., Sukernik, R. I. \& Wallace, D. C. (2002) The role of mtDNA background in disease expression: a primary LHON mutation associated with Western Eurasian haplogroup J. Hum Genet 110, 130138.

Carelli, V., Ghelli, A. \& Bucchi, L. (1999) Biochemical features of mtDNA 14484 (ND6/M64V) point mutations associated with Leber's hereditary optic neuropathy. Ann Neurol 45, 320-328.

Carelli, V., Giordano, C. \& d'Amati, G. (2003) Pathogenic expression of homoplasmic mtDNA mutations needs a complex nuclear-mitochondrial interaction. Trends Genet 19, 257-262.

Carlessi, R. M., Crispim, D., Waldow, V. A., Canani, L. H., Gross, J. L., Tschiedel, B., Souto, K. E. P. \& Roisemberg, I. (2004) O papel de dois polimorfimos no gene da UCP2 na patogênese do diabetes mellitus tipo 2. Resumos do $50^{\circ}$ Congresso Brasileiro de Genética (ISBN 85-89109-04-6). Eletronically available at: www.sbg.org.br.

Finnila, S., Lehtonen, M. S. \& Majamaa, K. (2001) Phylogenetic network for European mtDNA. Am J Hum Genet 68, 1475-1484.

Gerbitz, K. D., van den Ouweland, J. M. W., Maassen, J. A. \& Jaksch, M. (1995) Mitochondrial diabetes mellitus: a review. Biochim Biophys Acta 1271, 253-260.
Goto, Y., Nonaka, I. \& Horai, S. (1990) A mutation in tRNA(Leu)(UUR) gene associated with the MELAS subgroup of mitochondrial encephalomyopathies. Nature $\mathbf{3 4 8}$, 651-653.

Herrnstadt, C., Elson, J. L., Fahy, E., Preston, G., Turnbull, D. M., Anderson, C., Ghosh, S. S., Olefsky, J. M., Beal, M. F., Davis, R. E. \& Howell, N. (2002) Reduced-mediannetwork analysis of complete mitochondrial DNA codingregion sequences for the major African, Asian, and European haplogroups. Am J Hum Genet 70, 1152-1171.

Hofmann, S., Bezold, R., Jaksch, M., Obermaier-Kusser, B., Mertens, S., Kaufhold, P., Rabl, W., Hecker, W. \& Gerbitz, K. D. (1997) Wolfram (DIDMOAD) syndrome and Leber hereditary optic neuropathy (LHON) are associated with distinct mitochondrial haplotypes. Genomics 39, 8-18.

Kadowaki, T., Kadowaki, H., Mori, Y., Tobe, T., Sakuta, R., Suzuki, Y., Tanabe, Y., Sakura, H., Awata, T., Goto, Y. I., Hayakawa, T., Matsuoka, K., Kawamori, R., Kamada, T., Horai, S., Nonaka, I., Hagura, R., Akanuma, Y. \& Yazaki, Y. (1994) A subtype of diabetes mellitus associated with a mutation of mitochondrial DNA. N Engl J Med 330, 962968.

Kalman, B., Lublen, F. D. \& Alder, H. (1995) Mitochondrial DNA mutations in multiple sclerosis. Mult Scler 1, 32-6.

Katagiri, H., Asano, T., Ishihara, H., Inukai, K., Anai, M., Yamanouchi, T., Tsukuda, T., Kikuchi, M., Kitaoka, H., Ohsawa, N., Yazaki, Y. \& Oka, Y. (1994) Mitochondrial diabetes mellitus: prevalence and clinical characterization of diabetes due to mitochondrial tRNALeu(UUR) gene mutation in Japanese patients. Diabetologia 37, 504-510.

Kelley, D. E., He, J., Menshikova, E. \& Ritov, V. (2002) Dysfunction of mitochondrial in human skeletal muscle in type 2 diabetes. Diabetes 51, 2944-2950.

Lee, H. K. (2001) Method of proof and evidences for the concept that mitochondrial genome is a thrifty genome. Diabetes Res Clin Pract 54, S57-S63.

Lodi, R., Montagna, P., Cortelli, P., Iotti, S., Cevolli, S., Carelli, V. \& Barbiroli, B. (2000) Secondary 4216/ND1 and 13708/ND5 Leber's hereditary optic neuropathy mitochondrial DNA mutations do not further impair in vivo mitochondrial oxidative metabolism when associated with the 11778/ND4 mitochondrial DNA mutation. Brain 123, 1896-1902.

Perucca-Lostanlen, D., Narbonne, H., Hernandez, J. B., Staccini, P., Saunieres, A., Paquis-Flucklinger, V., Vialettes, B. \& Desnuelle, C. (2000) Mitochondrial DNA variations in patients with maternally inherited diabetes and deafness syndrome. Biochem Biophys Res Commun 277, 771775.

Petersen, K. F., Befroy, D., Dufour, S., Dziura, J., Ariyan, C., Rothman, D. L., DiPietro, C., Cline, G. W. \& Shulman, G. I. (2003) Mitochondrial dysfunction in the elderly: possible role in insulin resistance. Science 300, 1140-1142. 
Petersen, K. F., Dufour, S., Befroy, D., Garcia, R. \& Shulman, G. I. (2004) Impaired mitochondrial activity in the insulinresistant offspring of patients with type 2 diabetes. $N$ Eng $J$ Med 350, 664-671.

Poulton, J., Brown, M. S., Cooper, A., Marchington, D. R. \& Phillips, D. I. W. (1998) A common mitochondrial DNA variant is associated with insulin resistance in adult life. $D i$ abetologia 41, 54-58.

Reardon, W., Ross, R. J. M., Sweeney, M. G., Luxon, L. M., Pembrey, M. E., Hading, A. E. \& Trembath, R. C. (1992) Diabetes mellitus associated with a pathogenic point mutation in mitochondrial DNA. Lancet 340, 1376-1379.

Ross, O. A., McCormarck, R., Maxwell, L. D., Duguid, R. A., Quinn, D. J., Barnett, Y. A., Rea, I. M., El-Agnaf, O. M. A., Gibson, J. M., Wallace, D., Middleton, D. \& Curran, M. D. (2003) mt4216C variant in linkage with the mtDNA TJ cluster may confer a susceptibility to mitochondrial dysfunction resulting in an increased risk of Parkinson's disease in the Irish. Exp Gerontol 38, 397-405.

Suzuki, S., Oka, Y., Kadowaki, T., Kanatsuka, A., Kuzuya, T., Kobayashi, M., Sanke, T., Seino, Y. \& Nanjo, K. (2003) The Research Committee for Specific Types of Diabetes Mellitus with Gene Mutations of the Japan Diabetes Society, Clinical features of diabetes mellitus with mitochondrial DNA 3243 (A-G) mutation in Japanese: maternal inheritance and mitochondria-related complications. Diabetes Res Clin Pract 59, 207-217.

The Expert Committee on the Diagnosis and Classification of Diabetes Mellitus (1997) Report of the Expert Committee on the Diagnosis and Classification of Diabetes Mellitus. Diabetes Care 20, 1183-1197.

Thomas, F., Balkau, B., Vauzelle-Kervroedna, F. \& Papoz, L. (1994) for the CODIAB-INSERM-ZENEC Study Group.
Maternal effect and familial aggregation in NIDDM. The CODIAB Study Group. Diabetes 43, 63-67.

Torroni, A., Petrozzi, M., D’Urbano, L., Sellitto, D., Zeviani, M., Carrara, F., Carducci, C., Leuzzi, V., Carelli, V., Barboni, P., De Negri, A. \& Scozzari, R. (1997) Haplotype and phylogenetic analyses suggest that one European-specific mtDNA background plays a role in the expression of Leber hereditary optic neuropathy by increasing the penetrance of primary mutations 11778 and 14484. Am J Hum Genet 60, 1107-1121.

van den Ouweland, J. M. W., Lemkes, H. H. P. J., Ruitenbeek, W., Ruitenbeek, L. A., de Vijlder, M. F., Struyvenberg, P. A. A., van den Kamp, J. P. P. \& Maassen, J. A. (1992) Mutation in mitochondrial tRNALeu(UUR) gene in a large pedigree with maternally transmitted type II diabetes mellitus and deafness. Nat Genet 1, 368-371.

Vergani, L., Martinuzzi, A., Carelli, V., Cortelli, P., Montagna, P., Schievano, G., Carrozzo, R., Angelini, C. \& Lugaressi, E. (1995) MtDNA mutation associated with Leber's hereditary optic neuropathy: studies on cytoplasmic hybrid (cybrid) cells. Biochem Biophys Res Commun 210, 880-888. Yanovski, J. A., Diament, A. L., Sovik, K. N., Nguyen, T. T., Li, H., Sebring, N. G. \& Warden, C. H. (2000) Associations between uncoupling protein 2 , body composition, and resting energy expenditure in lean and obese African American, white, and Asian children. Am J Clin Nutr 71, 1405-1412.

Received: 23 May 2005

Accepted: 14 September 2005 